\title{
Evolution of the Sea Star Igkappa Gene
}

\author{
Michel Leclerc \\ 556 rue Isabelle Romée, 45640 Sandillon (France) \\ *Corresponding Author: Michel Leclerc, 556 rue Isabelle Romée, 45640 Sandillon (France)
}

\begin{abstract}
Next to the sea star T and B lymphocytes, the preservation of the IgKappa gene for so extended a period of evolution in organisms as distinctively different as sea star, fish, mammal, indicates that it plays an essential rôle in the survival of organisms : rôle in the regulation of immune response, in Asterids.The presence of $F c$ receptor gene, Fab gene in Asterias rubens complete these data.
\end{abstract}

\section{INTRODUCTION}

The purpose of this work is to draw attention to the mass of Igkappa genes that has accumulated on the sea star Immune system since 2011. From this year, genomes of immunized and nonimmunized sea stars to HRP (horse-radish peroxydase) have been studied (1). Although IgKappa gene has been isolated (2) and found in mouse, this gene has also been detected in fish (Zebra fish and Larimiththys crocea) and mammals. In this paper we will mainly review information on a fish : Larimiththys crocea and a mammal : Tupaia chinensis, to attempt to evoke Igkappa gene evolutionary considerations.

\section{RESULTS}

The sea star Igkappa gene is clearly the oldest IgKappa gene of the immune system of animals.

It shows already two Ig sites (Ref.2). The forms of Igkappa genes are all found in vertebrates, they share many details with the sea star, including the presence of Ig sites.

The preservation of the Igkappa gene in immunized and non-immunized sea stars is an excellent opportunity for further experiments.It is important to notice that the Igkappa chain VIII region HAH of Tupaia chinensis is situated (in the assumptions behind the theory of evolution) between the Igkappa chain precursor V-II region (RPMI/133) and Igkappa chain precursor V-IV region/121 The sequence of the anti-HRP IGKappa transcriptome is following (in 5'-3') :

5'TGATGAATCTCTTAAAATTATATTTAA
AAATTACAAATTAAAAATTATTTGATAT
TTTGTTCTGGCTCAAACCTTATTGTATTT
TGTGTTGTATCAAGACTATGTGCCTGGA

\section{CTTGGTTT}

GGGATCTTGCACCCCTAGGGTGGTTCTG TGGGGAACCGTGACAAGTGTTTCTGGAG GAAC

TTTTGTGAGAATTGTAGAAGAACACAAG TGAACCTCATGAACAAAGCAAACACCCA CTTT

GTCAGAGATAGATTATCCTGTTCACAAA TATCACAGTTATGCAGGTGTTTTTTGTTT TTT

TTCAATCTTTGTCTTTTTCAGACATTTAT GGCAATGCAGTCCAAGTATGCACAACCA ATG

TTTGTTTGTGGTAAATCTTTGTATGAAAA CTATGTGTTTATTCACACTGTGATATCTA CT

TAGTAAATTCATTCAATTTTCAGGGTTGA TGCTTTGTAAACTTTGCTTTTTGTATAAA AT

AAGGAAACATAAATGGAATGTGAGGTA

AAACAAAGTCAACAATGTACATAAATGT GGCCA

AGTCACACTAATGGGTTAAAAGATAACT

TTGTAAATGAGGCGTGAGACAAATGTAA CTTT

TTTGTCGCAGTCTTTTCCTGTACATTCAA AAGCTGTTCATGATTTTTCATTGCAAAAA TA

AATAAATTGACCTTAAGAAGTTACAAGG TCATATATTACTACAAAACCACGTTCCCC TCA

TATGTTACTCTTTTGTGCACATCAGTGTA GAACCACCCACATATGTATATTGCGCCA CTG

ACCTATGACATTTTGATGAATGCAATCG ATGTGTAACACTTGTGGAATATTGAAGT GTGT

GTAGTACAATGGCACATTGTCCGTGTTTT 
GTATAAAAATAGGAAATAAAATGGTACA CCA CT 3'

\section{CONCLUSION}

The preservation of the IgKappa gene for so extended a period of evolution in organisms as distinctively different as sea star, fish, rodent, mammal, indicates that it plays an essential rôle in the survival of the organisms, rôle in the regulation of the immune response.

Additionally, the existence of members of the IgKappa gene family with conserved functional characters, indicate that the sea star IgKappa gene has evolved prior to the evolutionary divergence between Invertebrate and Vertebrates: It must be claimed .

On the other hand, the discovery of a Fc receptor gene, of a Fab gene, in Asterias rubens genome corroborate the presence of the primitive Invertebrate antibody in asterids (IPA).

\section{REFERENCES}

[1] Leclerc M, et al. Immunol Lett 2011; 138 (19):7-198.

[2] Vincent N, et al. Metagene $2014 ; 2: 320-322$

[3] Zhulidov PA, et al. Nucleic Acid Res $2004 ; 3$ : 32-37

[4] Zerbino DR, et al. Gen Res 2007;18 : 821-829

Citation: Michel Leclerc, "Evolution of the Sea Star Igkappa Gene", International Journal of Research Studies in Medical and Health Sciences. 2020; 5(3): 27-28.

Copyright: () 2020 Michel Leclerc, This is an open-access article distributed under the terms of the Creative Commons Attribution License, which permits unrestricted use, distribution, and reproduction in any medium, provided the original author and source are credited. 